Андрій ТИЩЕНКО,

orcid.org/0000-0002-9847-2991

науковий співробітник бібліографічного відділу Державна наукова установа «Енциклопедичне видавництво»

(Україна, Київ)

vue.ped.psy@gmail.com

\title{
ЕМБЛЕМАТИЧНЕ ВТІЛЕННЯ СОБОРНОСТІ: ВІД РЕВОЛЮЦЇ̈ ДО СЬОГОДЕННЯ
}

\begin{abstract}
Дослідження торкається процесу утвердження державних символів, зокрема, питання створення та ухвалення великого Державного герба України. Соборність Украӥни розглядається, як головна складова державотворчого прочесу украӥнського народу.

Автор аналізує різні проекти Великого герба України від револючії до сьогодення через усталені в історіографії «виміри» соборності України: природно-географічного ландмафту на якому формувався український етнос; людському чиннику - саме українського етносу; культурно-духовного чиннику; організації суспільства - державного утворення; міжнародно - геополітичного чинника.

Ключові слова: соборність, державні символи, Великий герб Украӥни, Соборний герб Украӥни, Микола Битинський, проекти Великого герба Украӥни.
\end{abstract}

\author{
Andrew TYSCHENKO, \\ Research fellow at the \\ State Research Institution «Encyclopedia Press» \\ (Ukraine, Kyiv) \\ vue.ped.psy@gmail.com
}

\section{UNITY OF UKRAINE IN EMBLEMATIC REFLECTION FROM REVOLUTION (1917) TO PRESENT TIME}

The idea of the article is - approach to create the project of the Great Emblem of Ukraine not be based solely on the historical-geographical method or historical-national principle, which is now the leading one. Simultaneously, the use of the historical-geographical method and historical-national principle in the creation of the project of the Great Emblem of Ukraine is feature the attempts to image the idea of the Unity (Sobornist') of Ukraine in emblem, excluding other factors based culture, spirituality, religion, process of state formation, international and geopolitical influences.

Unity is the main value of the Ukrainian national idea and plays a prime role in the process of state rebuilding of Ukraine, especially now, when Russian Federation occupied Autonomous Republic of Crimea and support selfproclaimed republics in eastern Ukraine. The study of "Unity" Ukraine and its influence on state and national symbols is of practical importance, because the process of formation the state symbols of Ukraine not finished due to the problems of conceptual differences in the creation of the Great Emblem of Ukraine.

Unity as an idea and a phenomenon in Ukrainian historiography is object, subject of scientific knowledge, include that dimensions: a) geographical position b) formation of ethnic Ukrainian groups; c) factor of culture, spirituality, religion; d) process of state formation; e) factors of international and geopolitical influence. The study of factors determined important and actual among them.

Analyze conceptual ideas in the direction of create the Great Emblem of Ukraine (the projects coat of arms by M. Bytynsky, project by A. Grechylo, O. Kohan, etc.). Determines the role and place idea of the Unity of Ukraine in system of national and state symbols.

Studying and comparing various projects of we notice the tendency of the historical-geographical principle in the idea of the "Unity" in Great Emblem of Ukraine. Such an approach is logical and historically justified, but at the 
same time one-sided, because it will not fully reflect the place of the Crimea and other Ukrainian ethnic territories in the history of Ukraine, including historically Ukrainian outside the now independence state. Relatively last, the transformation of the idea Unity of Ukraine at the present stage based on the historical and geographical methodic is ineffective, similarly historical-national principle as well, because state not a monoethnicity, monoreligious but democratic. The rejection of traditional approaches in the emblematic "Unity" will allow us to develop a socioformative approach as promising today.

Accordingly, if we deny traditional conceptual approaches, it necessary search the alternatives, which will become max universal, covering the other factors of the Unity, for example: based on political order or law as the regulation a relationship between different religious, ethnic, gender and other identity.

Key words. Unity of Ukraine, state symbols, the Great Emblem of Ukraine, projects of state emblem Ukraine, Mykola Bytynsky.

Постановка проблеми. Соборність становить головну цінність української національної ідеї та займає провідну роль у процесі державотворення України. Сучасні події вкотре показують важливість ідеї соборності України та наслідки нехтування нею у політиці держави в минулому. Дослідження ідеї соборності України, в контексті державотворчого процесу українського народу, анонсує втілення соборності України на практиці 3 осмисленням ефективності такого впровадження. В нашому випадку символічного та емблематичного втілення. Відповідно, дослідження питання співвідношення та впливів соборності України на державну та національну символіку має практичну важливість тому, що процес становлення державної символіки України $€$ незавершеним через проблеми концептуальних розбіжностей у створенні великого Герба України та його ухвалення.

Метою дослідження $є$ визначення ролі та умовного означення ідеї соборності України в системі національної та державної символіки, що також передбачає аналіз концептуальних ідей у напрямі розробки проекту великого Герба України. Допоміжним засобом для реалізації мети дослідження є розгляд проблеми в контексті формування єдиного національного культурного простору України та спроба вироблення певних рекомендацій у роботі над створенням проекту великого Герба Держави.

Аналіз досліджень. Дослідження соборності, як ідеї, явища, події в історичному вимірі $є$ не новим - опубліковано більше сотні узагальнюючих $\mathrm{i}$ монографічних досліджень, статей, дисертаційних робіт (Калакура, 2015), але вони, як правило, прямо не торкаються або не розглядають символічне та 
емблематичне втілення ідеї соборності. Згадаємо «Державні відзнаки України» Миколи Битинського (Битинський, 1939), ідеї якого та їх історикогеральдичний аналіз, були підхоплені в актуальний час формування символіки держави у 1993 р. Володимиром Панченком у статті «Соборний герб України» (Панченко, 1993). У наш час подібні праці, що присвячені розробці державних символів у контексті ідеї соборності України є досить актуальними.

Універсальність вжитку поняття «соборності» - від філософськорелігійної сфери до політичного контексту, закономірно надає багатовимірності цьому терміну. Тому, не вдаючись до проблем етимології слова «соборність» слід попередньо виокремити основні складові «соборності України», які в історіографії виступають об'єктами та суб'єктами наукового пізнання (за Я. С. Калакурою): а) природно-географічний ландшафт на якому формувався український етнос; б) людський чинник - саме український етнос; в) культурнодуховний чинник; г) організація суспільства - державне утворення; д) міжнародний - геополітичний чинник (Калакура, 2009: 66).

Виклад основного матеріалу. Вищенаведене розчеплення поняття «соборності України» дозволяє зрозуміти, яка із складових впливає, є головною, актуальною для символічного втілення «соборності України» і що можливо називати «Соборним гербом України». Вибір такого базису, зумовлюється й часовою універсальністю чинників.

У книзі «Державні відзнаки України» М. Битинського (1939 рік) (Битинський, 1939) маємо 3 розроблені варіанти герба: малий, середній, великий.

Малий герб - тризуб Володимира Великого, що стилістично схожий на сучасний офіційний малий Герб України. Середній - щит якого заповнено символами п’яти історичних земель України, а в центр поміщено малий герб без жодних змін.

«Державний великий герб», який усталено називаємо «соборним», має в центрі малий герб без змін, щитотримачі тризуба $є$ архістратиг Михаїл та галицький лев - традиційні символи міст Києва та Львова. Навколо тризуба 
розташовані п'ять щитів, чотири 3 них мають в центрі герби українських історичних земель, п’ятий щит козака запозиченого iз символіки Чорноморського козацького війська.

Характеризуючи проект Битинського ми чітко бачимо реалізовані складові соборності: «природно-географічний ландшафт на якому формувався український етнос» та «людський чинник - саме український етнос», що передані автором через комбінацію гербів українських земель в різні історичні епохи, тобто проекти створено через використання історико-географічного методу. 3 іншого боку, автор реалізував й «державницьку» складову соборності, зобразивши в якості малого герба - тризуб Володимира, як свідчення першого могутнього державного утворення на українських землях, a також як герб УНР, 3 подальшим розміщенням малого герба в центрі середнього та великого. На середньому гербі тризуб вже оточують символи із гербів українських земель та з історії державотворення України: Київщина архангел Михаїл, Галичина або Галицько-Волинське князівство - золотий лев, голова буйвола - Бессарабію, козак - Чорноморське козацьке військо, а також окремо герб Карпатської України. В середньому гербі не вистачає символу або герба, який символізує Гетьманщину (тобто козака з мушкетом), тому цей варіант не претендує на повне розкриття теми українських державотворчих процесів та спадковості української держави на відміну від «Державного великого герба», що містить широке коло гербів включаючи й козака 3 мушкетом, можна погодитися з В. Панченком (Панченко, 1993: 2), що автор не приділяв уваги точності відтворення гербів але й можливо він це зробив умисно з оглядом на інші причини, адже Битинський грунтовно досліджував історію та геральдику (Кучерук, 2006: 400)

Повертаючись до складових соборності, можна стверджувати, що «культурно-духовний чинник» не є провідним та нехтується із застосуванням історико-географічного підходу до створення символіки, а отже не присутній у проекті Битинського на відміну від проекту Закону України від 10.09.2009 року № 5118 народних депутатів України Білозір О.В., Герман Г.М., Ващук К.Т. 
«Про великий Державний Герб України» (Проект № 5118, 2018). Запропонований законопроект нехтує історико-географічний підхід, висуваючи релігійну ідентичність на перше місце з додаванням до тризуба хреста та девізу: «3 нами Бог i Україна». Іншим прихильником використання релігійної ідентичності у створенні великого Державного Герба України є В. Мойсеєнко про що він пише у статті «Символи, які нас можуть об'єднати (стисле обгрунтування проекту Великого Герба України)» (Мойсеєнко, 2010: 118), цитуємо: «Головні складові герба - хрест і півмісяць означають для українських християн і мусульман небесне покровительство над нашою країною, 24 промені великого кола-сонця на хресті символізують усі області України, коло в центрі хреста - столицю країни м. Київ, а дві зірки Автономну Республіку Крим та м. Севастополь», а також «Таким чином тризуб на Малому Гербі України так і не став об'єднуючим символом для всіх громадян України. Сприяє цьому і та обставина, що українські історики та народознавці за останні сто років так і не спромоглися придумати для нього загальноприйнятну i захоплюючу легенду» (підкреслення наше. - Авт.).

Безперечно, розгляд релігії в якості чинника впливу на процеси державотворення України актуально для історії України. Звичайно, релігія в процесі державотворення іноді займала перше місце але зі зміною обставин, які не можуть бути сталими, втратила першочерговість. Якщо в козацькі часи ідентифікатор «православний» протистояв «ісламу» або «католицизму» - вони були антагоністами, то в сучасній Україні це питання не стоїть так гостро, а згідно Основного Закону України (Конституція України, 1996) маємо вільне віросповідання, а тому підхід до формування сучасної державної символіки на основі релігійної ідентичності не може бути основним та переважаючим, навіть якщо ми будемо ототожнювати цей підхід із «культурно-духовним чинником» - виокремленою складовою поняття «соборності України».

Аналогічна ситуація спостерігається 3 іншими чинниками, окрім державницького, котрий в наш час має можливість адміністративним шляхом регулювати релігійні відносини, здійснювати політичну діяльність на 
міжнародній арені, змінювати державний кордон, забезпечувати культурноосвітні потреби українців та інших етносів на території держави. Тобто, ми визначаємо «організаційно-державний чинник» на сучасному етапі розвитку головним, а отже в рамках його ми розглядаємо й ідею соборності України, як ідею єднання для збереження демократичного суспільства. Звісно, в рамках історичного процесу, в майбутньому можливе зростання важливості інших чинників але тільки шляхом розбудови правового, демократичного суспільства вони не будуть мати першочерговості перед організаційно-державницьким, що не має гострої необхідності в конфесійній, етнічній, культурній ідентифікації, а виконує загально регулятивну функцію.

Проблематика побудови ефективних регулятивних методів на сучасному етапі державотворення у рамках ідеї соборності України та соборності українців, в головному повинна базуватися не тільки за національним принципом, адже титульна нація - українці, але враховувати інтереси інших етносів. У таких умовах ідея соборності України має бути трансформованою на користь не суто українській мрії - незалежної української держави, що історично відбулася, а на збереження вже існуючої правової, демократичної формації. Наповнення таким змістом ідеї соборності України не є ординарною і на перший погляд не враховує національних інтересів, оскільки обгрунтовується на поза етнічному, територіальному i громадянському принципах, але це не означає, що українці асимілюються на етнокультурному рівні, адже це інше питання: ефективного впровадження культурно-освітньої політики.

На Всеукраїнському конкурсі на створення кращого проекту Державного герба України (1991р.) переможним став проект авторів А. Гречила, О. Кохана, I. Турецького. Окрім вже утвердженого Малого герба України, автори подавали на конкурс й проект Великого герба України. Зображення великого герба мало у собі малий герб, який тримали щитотримачі - воїн часів Київської Русі та козак з мушкетом із герба Гетьманщини, розміщені на гілках калини, перевитої синьо-жовтою стрічкою. Поява саме цих щитотримачів уособлює своїм 
символізмом державотворчі процеси українського народу (Тищенко, 2013: 196). Пізніше ця ідея стала провідною, прикладом є проект Закону України «Про Державний Герб України» 2009 року, автором законодавчої ініціативи виступила Ю. Тимошенко (Проект № 5118, 2018) та проект 3 аналогічною назвою 2016 року [Проект закону України № 4035 від 05.02.2016, Про Державний Герб України, 2016], який внесено на розгляд Ю. Левченком. В останньому проекті знаходимо текст: «Державний Герб України є символом новітньої Української Держави, який фокусує в собі головні етапи іiі становлення та багатовікового розвитку, слугує втіленням провідної національної ідеї - ідеї соборності українських земель».

Висновки. Не вдаючись до аналізу пропонованих проектів 3 точки зору геральдичних правил, головне, помічаємо тенденцію історико-географічного принципу в ідейній реалізації Великого герба України. Такий підхід є логічним та історично оправданим але в той час і однобічний, тому що повністю не зможе відобразити місце Криму в історії України та інших територій, в цьому числі етнічно та історично українських за межами держави. Тому, в рамках охарактеризованої нами трансформації ідеї соборності України на сучасному етапі, історико-географічна концепція не ефективна, аналогічно й істориконаціональний принцип також. Відповідно, при відхиленні традиційних концептуальних підходів, слід шукати альтернативні, що повинні мати максимальну «соборну»- об’єднавчу ефективність.

Підхід до формування ідеї соборності України за наведеними принципами дозволить прискорити процес становлення державних символів, що знаходить підтвердження через аналіз поширених або «розрекламованих» проектів Великого герба України.

\section{СПИСОК ВИКОРИСТАНИХ ДЖЕРЕЛ І ЛІТЕРАТУРИ}

1. Битинський, 1939 - Битинський М. О. Державні відзнаки України. Б. м. 1939. 
2. Калакура, 2015 - Калакура Я. С. Соборність України в інтер'єрі новітньої історіографії // Соборність України: історичний контекст і виклики сьогодення: матеріали круглого столу. К., 2015. С. 35-50.

3. Калакура, 2009 - Калакура Я. С. Українська соборність як історіографічна проблема // Соборність як чинник українського державотворення (до 90річчя Акту злуки): Всеукр. наук. конф., 21 січ. 2009 р. К., 2009. С. 65-67.

4. Конституція, 1996 - Конституція України. Закон України від 28 червня 1996 року № 254к/96-ВР, із зм. і доп. // Відомості Верховної Ради України. 1996. № 30. Ст. 141.

5. Кучерук, 2006 - Кучерук О. Микола Битинський - геральдист, історик, митець // Український археографічний щорічник. К., 2006. № 10/11. С. 398419.

6. Мойсеєнко, 2010 - Мойсеєнко Валентин. Символи, які нас можуть об'єднати (стисле обгрунтування проекту Великого Герба України) // Освіта регіону: Політологія. Психологія. Комунікації: укр. наук. журн. 2010. № 2. С. 118-120.

7. Панченко, 1993 - Панченко В. О. Соборний герб України. К., 1993. 48 с.

8. Проект № 4035, 2018 - Проект закону України № 4035 від 05.02.2016, Про Державний Герб України // Ліга: закон, 20 червня 2018. [Електронний pecypc]. Режим доступу: http://search.ligazakon.ua/__doc2.nsf/link1/JH34300A.html

9. Проект № 5118, 2018 - Проект закону України від 10.09.2009, Про великий Державний Герб України // Ліга: закон, 20 червня 2018. [ [Електронний pecypc]. доступу: http://search.ligazakon.ua/1_doc2.nsf/link1/JF3Y600A.html

10. Тищенко, 2013 - Тищенко А. О. Всеукраїнський конкурс на створення кращого проекту Державного герба України (1991р.) // Національна та історична пам'ять. 2013. №8. С. 191-198. 


\section{REFERENCES}

Bytynskyi, 1939 - Bytynskyi M. O. Derzhavni vidznaky Ukrainy. [State symbols of Ukraine]. Self-Published, 1939. [in Ukrainian].

Kalakura, 2015 - Kalakura Ya. S. Sobornist Ukrainy v interieri novitnoi istoriohrafii [The Unity of Ukraine in the interiors of modern historiography] // Sobornist Ukrainy: istorychnyi kontekst i vyklyky sohodennia: materialy kruhloho stolu. K., 2015. S. 35-50. [in Ukrainian].

Kalakura, 2009 - Kalakura Ya. S. Ukrainska sobornist yak istoriohrafichna problema [The Unity of Ukraine as a historiographic problem] // Sobornist yak chynnyk ukrainskoho derzhavotvorennia (do 90-richchia Aktu zluky): Vseukr. nauk. konf., 21 sich. 2009 r. K., 2009. S. 65 - 67. [in Ukrainian].

Konstytutsiia, 1996 - Konstytutsiia Ukrainy. Zakon Ukrainy vid 28 chervnia 1996 roku № 254k/96-VR, iz zm. i dop. [Constitution of Ukraine. Law of Ukraine dated June 28, 1996 № 254к/96-BP] // Vidomosti Verkhovnoi Rady Ukrainy. 1996. № 30. pt. 141. [in Ukrainian].

Kucheruk, 2006 - Kucheruk O. Mykola Bytynskyi - heraldyst, istoryk, mytets [Mykola Bitynsky is a heraldist, historian, artist] // Ukrainskyi arkheohrafichnyi shchorichnyk. K., 2006. Issue №10/11. S. 398-419. [in Ukrainian].

Moiseienko, 2010 - Moiseienko Valentyn. Symvoly, yaki nas mozhut obiednaty (stysle obgruntuvannia proektu Velykoho Herba Ukrainy) [The symbols of unite (short justification of the project of the Great Emblem of Ukraine)] // Osvita rehionu: Politolohiia. Psykholohiia. Komunikatsii: ukr. nauk. zhurn. 2010. № 2.S. 118-120 [in Ukrainian].

Panchenko, 1995 - Panchenko V. O. Sobornyi herb Ukrainy [Emblem of Unity Ukraine]. K., 1995. 48 s. [in Ukrainian].

Proekt № 4035, 2018 - «Proekt zakonu Ukrainy № 4035 vid 05.02.2016, Pro Derzhavnyi Herb Ukrainy» [Project of Law of Ukraine No. 4035 dated February 5, 2016, On the State Emblem of Ukraine] Liga: zakon, June 20, 2018. [Elektronnyi resurs]. Rezhym dostupu: http://search.ligazakon.ua/__doc2.nsf/link1/JH34300A.html [in Ukrainian]. 
Proekt № 5118, 2018 «Proekt zakonu Ukrainy № 5118 vid 10.09.2009, Pro velykyi Derzhavnyi Herb Ukrainy» [Project of Law of Ukraine No. 5118 dated September 10, 2009, On the Great State Emblem of Ukraine] Liga: zakon, June 20, 2018. [Elektronnyi resurs]. Rezhym dostupu: http://search.ligazakon.ua/__doc2.nsf/link1/JF3Y600A.html [in Ukrainian].

Tyshchenko, 2013 - Tyshchenko A. O. Vseukrainskyi konkurs na stvorennia krashchoho proektu Derzhavnoho herba Ukrainy (1991 r.) [Ukrainian Contest for the creation of the best project of the State emblem of Ukraine (1991)] // Natsionalna ta istorychna pamiat. 2013. №8. - S. 191-198. [in Ukrainian]. 